\title{
THE VARIETIES OF HOMEWORK GIVEN BY ENGLISH TEACHERS OF VOCATIONAL SCHOOLS
}

\author{
Dinar Martia Azizah \\ Department of Primary Teacher Education, Faculty of Teacher Training and Education, University of \\ Sarjanawiyata Tamansiswa, Indonesia \\ Email: dinar.azizah@ustjogja.ac.id
}

APA Citation: Azizah, D. M. (2018). The varieties of homework given by English teachers of vocational schools. Indonesian EFL Journal, 4(2), 48-55. doi: 10.25134/ieflj.v4i2.1375.

Published: 01-07-2018

\begin{abstract}
Learning inside the classroom is never enough because there are various limitations, so it needs the non-school hour assignment called homework. This research aims to find out the varieties of homework given by English teachers of vocational schools. This research uses a qualitative descriptive method by involving eight English teachers of vocational schools in Yogyakarta. Open-ended questionnaires, interview, and document analysis are used to collect the data. In analyzing the obtained data, the researcher does three steps, namely data condensation, data display, and conclusion drawing. The research results showed that homework varieties given by English teachers serve three main objectives. Those objectives are to broaden knowledge, sharpen skills, and inculcate values. It is concluded that formal education in schools requires homework that improve students' English proficiency. Besides, the existence of State Examination is regarded as a special thing that effects on learning process.
\end{abstract}

Keywords: homework; broaden knowledge; sharpen skills; inculcate values; English proficiency.

\section{INTRODUCTION}

Teachers, as one of learning components, wherever and whenever hope to get the best result in teaching. They do various efforts and activities. One of the common efforts and activities that teachers do for any learning, including English, is using homework to support learning outside classrooms. Homework is any task assigned by school teachers intended for students to carry out during non-school hours (Cooper, Robinson, $\&$ Patall, 2006). Homework probably involves complex interaction (Sharp, Keys, \& Benefield, 2001). It implies that homework involves interaction of various components of learning.

Homework is seen as one of rituals (that is practices prescribed by custom) in schools (Trowbridge, 2010; O'Connor, 2009). Homework is a long-standing education tradition that, until recently, has seldom been questioned. It can be concluded that the existence of homework is seen as an integral part of education for long time (Votterott,
2009). Yet, it is still possibly used by many teachers around the world until now.

Every teacher has a different effort to develop a variety of homework. Teachers' homework practices vary in quality. They may apply best practice standards, assign too difficult homework, or collect homework without providing feedback (Protheroe, 2009). There are teachers who effectively use homework to meet the needs of students with their strengths and make up the weakness of the learning components. In other case, some teachers use homework as a series of learning without considering the follow-up activities for the homework and their benefits for students.

Homework is viewed as one of several strategies that teachers can use to show children that learning takes place everywhere (Cooper, 2001). Homework can also be seen as one of the learning methods applied by teachers. There are three various possibilities of using homework as the learning strategies, namely: 1) Material review - practice the 
material that has already been presented in class (Becker \& Epstein, 1982; Cooper, Robinson, \& Patall, 2006); 2) Preparation assignments - introduce new material (Cooper, Robinson, \& Patall, 2006); and 3) Extension homework - transfer the previously learned skills to new situations (Lee \& Pruitt, 1979; Cooper, Robinson, \& Patall, 2006).

Teachers may apply homework, as a learning strategy, for various purposes, such as reviewing the material, introducing new materials and correlating new material to the previous ones. Based on these goals, the function of material review is the most frequent reason why homework is given by teachers (Becker \& Epstein, 1982; Cooper, Robinson \& Patall, 2006). In other words, the most common instructional purpose of homework is to provide the students an opportunity to practice the material that has been taught.

Here, the researcher has her own reasons for choosing the topic. First, the researcher chooses a topic of homework varieties because learning inside a classroom is never enough due to various limitations, so it needs the nonschool hour assignment that is called homework. Second, the reason for choosing vocational school is that it trains the students to become human resources that may be able to use English in more practical ways than students of senior high schools. The results of this study are expected to be inspiring and can be input for the parties in education in general, and English teachers in particular.

\section{METHOD}

This research employs a qualitative descriptive method. The data are collected through open ended questionnaires, interview, and document analysis. The questionnaires are given to eight English teachers of vocational schools in Yogyakarta. The teachers are then interviewed to get information about the reasons of giving homework. In addition, the researcher also conducts document analysis toward syllabus, State Examination passing standards, and State Examination item bank. In analyzing the obtained data, the researcher does three steps, namely data condensation, data display, and conclusion drawing (Miles, Huberman \&
Saldana, 2014). Firstly, data from questionnaires, document, and interview are selected and transcribed. Then, the researcher organizes and describes the data. Finally, the researcher draws the conclusion and verifies it.

\section{RESULTS AND DISCUSSION}

Based on data analysis, it is concluded that homework given teachers serves three main purposes. Those purposes are to broaden knowledge, sharpen skills, and inculcate values.

\section{Broaden knowledge}

Homework, that are aimed to broaden knowledge, are used for preparing upcoming lesson, preparing strategy of state examination, collecting materials of state examination, doing state examination exercises, learning vocabulary, learning grammar, learning language function, comprehending text, and discussing materials. The data are described below.

\section{Homework for preparing upcoming lesson}

Teachers ask students to read the material before teaching-learning process. Here are the statements given by English teachers through the interviews.

I ask students to read learning material for the next meeting (Teacher B).

Reading for the next material to reinforce the upcoming learning process (Teacher D).

Data show that preparing the upcoming lesson through a homework is done by teachers in order to make the students understand the material for the next meeting. A theory claims that preparation, one of homework purposes, is to introduce material to help students obtain the maximum benefit when the new material is covered in class (Cooper, Robinson, \& Patall, 2006).

\section{Homework for preparing strategy of state examination}

Data in this category show that homework is given by teachers to introduce their students some strategies to prepare for the State Examination. This is evident in the questionnaire and interview excerpts below.

They analyze a listening, an error recognition, a reading comprehension, an incomplete sentence, 
and a close test based on passing criteria standard of State Examination (Teacher C).

Identifying kinds of expression found in listening test of State Examination and analyzing kinds of expression used in dialogues of State Examination item bank (Teacher F).

Students translate downloaded State Examination materials in order to be more easily understood. They also translate State Examination item bank (texts, dialogues, e.tc) that have been taught (Teacher $\mathrm{H}$ ).

The data in this category show that some English teachers give homework that focus on State Examination. The teachers hope that students deeply understand types of test and materials of State Examination to make them successfully answer the test. They ask students to identify and analyze materials on passing criteria standard and State Examination item bank. Therefore, students will memorize sequence of test.

Another teacher gives homework that requires students to translate State Examination materials. Students have to download the materials on the internet that will be translated. They also translate the problems found on State Examination item bank. The teacher thinks that the translated materials will be more easily understood by the students.

Passing standards and State Examination item bank are used to become references to determine homework topics and materials in order to prepare the test. This conclusion is in line with a research conducted on a survey of 1000 American teachers which focused on issues related to homework. It shows that $86 \%$ of U.S. public school teachers reported frequently assigning homework to help students prepare for tests (Metlife, 2007).

\section{Homework for collecting materials of state examination}

Teachers ask students to browse kinds of text and download other materials based on passing standards of State Examination from internet and other sources. Teachers also ask students to make clipping of texts and dialogue of State Examination item bank. Data in this category show that homework is given by teachers to motivate students to deeply understand various text materials that are usually tested in State Examination.

Downloading all materials based on passing criteria standard of State Examination from other sources (recount, procedure text, etc.) (Teacher $\mathrm{H})$.

Students browse a report, an announcement, and a procedure text. They also have to find grammar materials to get more State Examination materials (Teacher F).

Students make a paper/clipping of short functional text based on passing criteria standard of State Examination: memo, invitation, schedule, and dialogues found in State Examination item bank (Teacher C).

The conclusion of this category is that homework can be used to lead students to be more autonomous by finding and collecting various texts tested in State Examination on the internet and other resources. The conclusion is in line with a theory explaining that self-directed learning can be enhanced with homework by requiring students to use outside resources like libraries, the internet and various reference materials (Booth, 2010).

\section{Homework for doing state examination exercises}

Data in this category show that teachers give students homework that require them to complete State Examination exercises. Those are making a short dialogue based on given situation, making a subjunctive sentence, making a conditional sentence, using various expressions to make a dialogue, and answering multiple choice questions. Homework require students to learn about language function but they do not learn all language function and grammar rules. Here are the statements from teachers.

Students complete sentences by using various expressions and make a short dialogue which usually found in State Examination based on given situation, e.g. giving suggestion that is performed in pairs (Teacher $\mathrm{F}$ ).

I ask students to write a reservation dialogue, a complaint dialogue, an application letter, a subjunctive sentence, and conditional sentence to deepen State Examination materials (Teacher C).

Using various expressions to make a dialogue and answering multiple choice questions to do exercise State Examination (Teacher $\mathrm{H}$ ).

Students are focused on learning certain materials that are usually tested in State Examination. They also hope that by giving 
homework, students will be familiar to the kinds of problem that are usually found in State Examination so that they can answer the test correctly. The conclusion is in line with a theory claims that one of homework types is for study. It implies that if the homework assignment is to study for the test, teachers should encourage students to organize notes, answer test, or study with a partner (Vatterott, 2010).

\section{Homework for learning vocabulary}

Teachers give homework that require students to complete vocabulary exercises. Below are the results of questionnaires and interviews with teachers.

Students find/look for a word in a passage (it can be a difficult word, adjective word, etc. related to the topic discussed) and matching a word with its synonym and definition to improve students' vocabulary mastery (Teacher A).

Filling in the blank of a sentence, a text, and a dialogue with the most appropriate word (Teacher E).

The exercises are matching a word to another word having similar meaning, choosing words that are appropriate to sentence context, and introducing new words found in a text that has been read before. Teachers hope that the exercises can improve students' vocabulary mastery. It is in line with a research conducted by Emami (2014) which showed that students who received homework had a better understanding of the vocabulary that was taught.

\section{Homework for learning grammar}

Homework is given by teachers to review grammar materials that have been learned by using various exercises. Here are the statements from teachers.

They have to write a sentence based on grammar discussed (Teacher B).

Students change verbs in parentheses into right form (tenses), change an active into passive voice, and make other sentences by applying tenses learned (Teacher D).

Making a sentence based on example of tenses given and recognizing errors on sentences (analyzing grammatical errors) (Teacher A).

Filling in the blank by using a correct grammar rule (Teacher $\mathrm{G}$ ).

Students should change words or sentences to other forms and make new sentences based on grammatical rules learned. Teacher also asks students to analyze some grammatical errors to understand more about grammar. Homework can be a filling in the blank type. It aims to support students in understanding the verb changes based on sentences context. Data in this category are in line with a theory showing that one of homework's purposes is to reinforce materials that has already been presented in class (Paulu, 1998). Another theory that supports this conclusion explains that teacher should give homework and exercises to force students to practice and revise the new structure (Foppoli, 2008).

\section{Homework for learning language function}

Teachers give students homework to apply and integrate language function concept on a dialogue and a sentence context. Below are the results of interview with teachers.

Students make a dialogue by using certain expression and arrange a jumbled expression to become a good dialogue (Teacher B)

I ask students to answer some questions of language function material, such as filling in the blank of a dialogue by using certain expression, choosing correct expressions then arrange them to become a good dialogue based on picture sequence, etc. (Teacher A)

Data in this category show that homework requires students to understand kinds of expression to arrange a good dialogue and answer language function exercises. It is in line with a theory that teachers should create homework that challenge students to apply and integrate a concept, information or ideas (Paulu, 1998).

\section{Homework for comprehending text}

Teachers give students homework that requires students to find important information of a text in various ways. This is evident in the interview excerpts below.

They read the text, then make a conclusion and summary (Teacher B).

Reading text, finding main idea of each paragraph and other information of a text (Teacher D).

Students answer some questions based on a text to find important information (Teacher $\mathrm{E}$ ).

These ways are making a conclusion, making summary, reading, finding and combining main idea of each paragraph, and 
answering questions based on a text. Data in this category is in line with a theory showing that homework reinforces and helps learners to retain information (Darn, 2007).

\section{Homework for discussing materials}

Homework can be an out-class-discussion activity that requires students to discuss certain learning materials in order to support their language proficiency. Here are the statements from teachers.

Homework requires them to explore some information by discussing the recent issues (Teacher G).

I also ask them to discuss a topic in a group that has been learned in class and the conclusion is presented on the next meeting (Teacher D).

The conclusion of this category is that an out-class-discussion enables students to negotiate their knowledge, skills, and belief with others in order to deepen their learning materials. This conclusion is in line with two theories. First theory is that students take responsibility for their learning when they participate in out-of-class activities and discuss with others what they are learning in classes to apply it to other aspects (Kuh, 1994). The second theory is that students discuss, explain, re-examine concepts, thereby reinforcing their learning, question and discuss complex concepts with each other (College Board, 2010; Booth, 2010).

\section{Sharpen skills}

One of homework purposes is for increasing students' language proficiency (Northwest Regional Educational Laboratory, 2005) in Blazer (2009). In learning English, the skills include listening, speaking, reading, and writing.

\section{Homework for supporting listening skill}

The obtained data show that listening skill can be learned through outclass individual exercises that are convenient to students' own interest, such as students' favorite videos and songs. Below are some of their statements in the interviews.

Listening an English video on youtube and making its transcript (Teacher $\mathrm{H}$ )

Students make a transcript of favorite English song to learn listening skill (Teacher G)
Listening skills, reading, communicating ideas, taking notes, problem solving, planning and prioritizing are skills that are often reinforced through homework assignments (Booth, 2010). Furthermore, listening to a song at home and watching a short video are great idea for students to learn listening outclass (Trowbridge, 2010).

\section{Homework for supporting speaking skill}

Data show that kinds of speaking exercise are making an English video, performing a drama, making a spoken daily conversation, discussing a topic that have been mentioned in class and the result is presented on the next meeting, presenting problem solving of a problem, performing self-introduction, and orating an English speech. Here are some of their statements.

My students make an English video in group to practice speaking (Teacher $\mathrm{H}$ ).

Writing a drama with daily life topic and performing it in a group. I also ask them to discuss a topic in a group that have been learned in class and the conclusion is presented in the next meeting (Teacher D).

Asking all students to present an opinion, presenting problem solving of a problem, writing and orating an English speech (Teacher A).

Making a daily conversation (spoken and written dialogue) in a pairs and performing selfintroduction (Teacher F)

It means that homework can be given to support speaking skill through group and individual exercises. This conclusion is supported by a theory that one of requirements of effective speaking homework may be assigned to different ability groups. Individual learning styles should be taken into account (Darn, 2007). A study conducted by Provenzano and Yue (2011) show that oral English homework given to students of a university in Japan make the speaking activity more enjoyable. These assignments require certain strategies to make can be beneficial for their speaking skills.

\section{Homework for supporting reading comprehension}

Teachers ask students to read and find information of texts. They are also required to answer some questions based on the text. 
The varieties of homework given by English teachers of vocational schools

Read a text, then make an application letter, some informal texts, etc. (Teacher E).

Ask them to read an example of menu list, English expressions, and other information on the internet (Teacher B).

Reading an example of text owned by students, finding information of a text, and aswering questions based on a text (Teacher A).

The teacher hopes that by doing homework, students' reading comprehension will be improved. This conclusion is in line with a theory mentions that homework can improve your child's general knowledge, and his grades improve but your child would also increase mastery of basic academic skills, such as reading, writing, and spelling (Goldstein \& Zentall, 1999).

\section{Homework for supporting formal text writing}

Data in this category show that teachers give homework that require students to write various formal texts such as a paper, a biography of an inspiring person, an application letter, a formal invitation letter, a formal announcement, dialog in a formal situation, and an English speech. Below are some statements taken from interviews and questionnaires.

Asking students to write a formal invitation letter, a formal announcement (at school, airport), paper/ portfolio, dialog in a formal situation (Teacher B).

Read a text, then make an application letter (Teacher E).

Making a text with a serious topic, e.g. a biography of an inspired figure, writing and orating an English speech (Teacher A)

The conclusion of this category is that teachers regard that various kinds of formal writing are important to be introduced to students through homeworks. It is in line with a theory claims that homework tends to focus on a formal written product (Darn, 2007).

\section{Homework for supporting informal text writing}

Data show that teachers ask students to write a daily conversation, list of students' daily activities, a receipt/procedure to make student's favorite food, student's own story in the past, and other informal texts. Below are some statements taken from interviews and questionnaires.

Making a students' daily activities list, writing about student's own story in the past (Teacher E)
Students write a recipt/procedure to make student's favourite food and other informal texts (Teacher G)

Writing a drama with a daily life topic and performing in a group, an informal descriptive, recount, and procedure text (Teacher $\mathrm{D})$.

Making a daily conversation (spoken and written dialogue) in a pairs (Teacher F)

The conclusion of this category is that homework requires students to write an informal text with a topic related to students' life. This conclusion is supported by a theory that as with extensive tasks, it is important for learners to share their experiences, and perhaps to collect them in an informal writing (Darn, 2007).

\section{Homework for supporting writing a translation}

Data in this category show that homework require students to translate English writing into Indonesian such as an English song, movie, etc. Below is the data obtained from interviews and questionnaires.

Translating an advertisement, a letter, an announcement, some paragraphs of a text to make students easily understand the information (Teacher A).

They translate an English text into Indonesian (Teacher B).

Students translate an English song, movies, products, etc (Teacher G).

Teacher believes that by translating an English text, students will easily understand the information in the text. This conclusion is in line with two theories. Translation can be a support for the writing process, especially at lower levels (Kaye, 2009). The second theory is also explained by Kaye (2009) who conducts a research that has shown that learners seem able to access more information in their own L1, which they can then translate.

\section{Inculcate values}

Homework aims to inculcate values that include individual and social values. Those are described below.

\section{Homework for inculcating individual value}

The given homework aims to inculcate a positive value on each student. Teachers give homework to inculcate value by relating learning material to students own interest and 
experiences in their lives. Here are some of their statements.

Writing about student's own story in the past, making a students' daily activities list (Teacher E)

Asking all students to present an opinion, presenting problem solving of a problem, making $a$ text with a serious topic, e.g. a biography of an inspired figure (Teacher A).

Students make a transcript of favorite English song to learn listening, make a recipe/procedure to make student's favorite food (Teacher G).

It is in line with a theory that homework enable students to use their abilities to produce individualized and creative work products (Horowitz, 2005; Corno, 2000; Nuzum, 1998; Doyle \& Barber, 1990; Blazer, 2009). Moreover, homework help students develop good attitude, such as self-discipline and responsibility (Paulu, 1998).

\section{Homework for inculcating social value}

Teachers ask students to complete both oral and written homework that require cooperation among students and orient students' care toward everything that happens in their environment. Below are some statements taken from interviews and questionnaires.

Homeworks require them to explore some information by discussing the recent issues (Teacher G).

They write a drama with daily life topic and performing it in a group. I also ask them to discuss a topic in a group that have been learned in class and the conclusion is presented in the next meeting (Teacher D).

Making an English video in group to practice speaking (Teacher $\mathrm{H}$ )

Making a daily conversation (spoken and written dialogue) in pairs (Teacher $\mathrm{F}$ )

Data show that teachers give students homework that enable them to maintain social relationship among students. It is in line with a theory showing that the planning of cooperative groups or suggesting and encouraging study groups are beneficial (Kagan, 1994).

\section{CONCLUSION}

The overall literature review and results of this research have explained that the existence of homework cannot be separated to various components of learning. In fact, every school has different learning components. These varieties are possibly making teachers require various homeworks to adjust the conformity among the learning component varieties. In other words, the entire discussion shows that the varieties of homework are systematically determined by various components.

This study aims to describe a variety of homework given by English teachers of vocational schools in Yogyakarta. The data are categorized into three major categories, namely broaden knowledge, sharpen skills, and inculcate values. The researcher classifies categories of broaden knowledge into homework for preparing upcoming lesson, preparing strategy of state examination, collecting materials of state examination, doing state examination exercises, learning vocabulary, learning grammar, learning language function, comprehending text, and discussing materials. The second major category is sharpen skills. Those item are homework for supporting listening skill, speaking skill, reading comprehension, formal text writing, informal text writing, and writing a translation. The last category is inculcate values that can be classified into homework for inculcating individual value and social value.

Based on the data, it is concluded that formal education in schools requires homework that improve students' English proficiency. Besides, the existence of State Examination is regarded as a special thing that effects on learning process. Some English teachers use State Examination passing standards and State Examination item bank as homework material references. State Examination preparation causes some English teachers to give homework as a strategy for doing a test, collecting additional materials, and doing the exercises.

\section{REFERENCES}

Blazer, C. (2009). Literature review homework. Florida: Miami-Dade County Public Schools.

Booth, G. I. (2010). The effects of homework assessment on student motivation and achievement. Washington: Central Washington University.

Cooper, H., Robinson, J. C., \& Patall, E. A. (2006). Does homework improve academic achievement? A synthesis of research 1987-2003. Journal of Education, 76(1), 1-62. 


\section{Dinar Martia Azizah}

The varieties of homework given by English teachers of vocational schools

Cooper, H. (2001). The battle over homework. California: Corwin Press.

Darn, S. (2007). GME: Homework. Retrieved from http://www.stevedarn.com/?Writings:Publications: GME\%3A_Homework.

Emami, A. (2014). Extension homework and classroom assignments. Journal of Novel Applied Sciences, 3(1), 29-39.

Foppoli, J. (2008). Is grammar really important for a second language learner? Retrieved from http://www.eslbase.org/articles/grammar.

Goldstein, S., \& Zentall, S. (1999). Seven steps to homework success: A family guide for solving common homework problems. New South Wales: Specialty Press, Inc.

Kagan, S. (1994). Cooperative learning. California: Kagan Publishing.

Kaye, P. (2009). Translation activities in the language classroom. Retrieved from http://www.teachingenglish.org.uk/article/translati on-activities-language-classroom.

Kuh, G. D. (1994). Student learning outside the classroom: Transcending artificial boundaries. Retrieved

from
MetLife. (2007). The metlife survey of the American teacher. US: MetLife, Inc.

Miles, M. B., Huberman, A. M., \& Saldana. (2014). Qualitative data analysis: A methods sourcebook ( $3^{r d}$ ed.). Los Angeles: Sage.

O'Connor, K. (2009). How to grade for learning $\mathrm{K}-12$ (3rd ed.). California: Corwin.

Paulu, N. (1998). Helping your students with homework: A guide for teachers. Washington, D.C: U.S. Department of Education.

Protheroe, N. (2009). Good homework policy. Retrieved from www.naesp.org.

Provenzano, C., \& Yue, S. (2011). Take it outside! Speaking homework for English communication classes. Intercultural Communication Studies, 20 (2), 220-238.

Sharp, C., Keys, W., \& Benefield, P. (2001). Homework: A review of recent research. Berkshire: NFER.

Trowbridge, S. (2010). Kids and homework. Retrieved from http://www.teaching english.org.uk/teachingkids/kids-homework.

Vatterott, C. (2010). Five hallmarks of good homework. Educational Leadership, 68(1), 10-15. .//www.learn2study.org/teachers /outside_classroom.htm. 